\title{
Methylocystis hirsuta sp. nov., a novel methanotroph isolated from a groundwater aquifer
}

Correspondence

Angela S. Lindner alind@eng.ufl.edu

\author{
Angela S. Lindner, ${ }^{1}$ Adriana Pacheco, ${ }^{1}$ Henry C. Aldrich, ${ }^{2} \dagger$ \\ Andria Costello Staniec, ${ }^{3} \| k e r ~ U z^{4} \ddagger$ and David J. Hodson ${ }^{1} \S$
}

\author{
'Department of Environmental Engineering Sciences, University of Florida, Gainesville, \\ FL 32611-6450, USA \\ ${ }^{2}$ Department of Microbiology and Cell Science, University of Florida, Gainesville, FL 32611-0700, \\ USA \\ ${ }^{3}$ Department of Civil and Environmental Engineering, Syracuse University, Syracuse, \\ NY 13244-1240, USA \\ ${ }^{4}$ Department of Soil and Water Sciences, University of Florida, Gainesville, FL 32611-0290, USA
}

Species of the genus Methylocystis are strictly aerobic, Gram-negative bacteria that are able to grow on onecarbon compounds (e.g. methane or methanol) (Bowman et al., 1993). The genus Methylocystis belongs to the class Alphaproteobacteria and currently consists of three species with standing in nomenclature, Methylocystis parvus, Methylocystis echinoides and Methylocystis rosea (Whittenbury et al., 1970; Gal'chenko et al., 1977; Bowman

\section{tDeceased 9 August 2005.}

‡Present address: Gaziosmanpasa University, Tokat Meslek Yuksekokulu, Oda No: 26, Tasliciftlik kampusu, 60250 Tokat, Turkey.

§Present address: Staff Engineer, CH2M Hill, 155 Grand Avenue, Suite 1000, Oakland, CA 94612, USA.

Abbreviations: $\mathrm{PHB}$, poly- $\beta$-hydroxybutyrate; $\mathrm{pMMO}$, particulate methane mononoxygenase; sMMO, soluble methane monooxygenase; TEM, transmission electron microscopy.

The GenBank/EMBL/DDBJ accession numbers for the 16S rRNA gene sequence and partial $m x a F, m m o X$ and $p m o A$ gene sequences of strain $\mathrm{CSC}^{\top}$ are respectively D0364433, D0664499, D0664498 and DQ364434.

Neighbour-joining trees based on partial mmoX and mxaF gene sequences and results of electron microscope cytochemistry of the S-layer of strain $\operatorname{CSC}^{\top}$ are available as supplementary material with the online version of this paper. et al., 1993; Wartainen et al., 2006). Numerous Methylocystis strains have been identified in a variety of environments, including lake, ocean, marsh and creek sediments and water, coal mine drainage water and the roots of plants (Whittenbury et al., 1970; Gal'chenko et al., 1977; Bowman et al., 1993; Hanson \& Hanson, 1996; Calhoun \& King, 1998; Heyer et al., 2002).

Species of the genus Methylocystis are type II methanotrophs, classified, in part, by their possession of paired membranes aligned with the cell periphery, the serine pathway and predominant fatty acids with 18 carbons (Hanson \& Hanson, 1996; Graham et al., 2002). Until recently, it was believed that all type II methanotrophs, including Methylocystis species, express the particulate form of methane monooxygenase (pMMO), and, with the exception of Methylocystis parvus $\mathrm{OBBP}^{\mathrm{T}}$ and the recently reported Methylocystis rosea $\mathrm{SV}^{2} 7^{\mathrm{T}}$, all express the soluble form of methane monooxygenase (sMMO) at low copper concentrations (Stanley et al., 1983; Prior \& Dalton, 1985; Choi et al., 2003; Wartiainen et al., 2006). Methylocystis parvus $\mathrm{OBBP}^{\mathrm{T}}$ and Methylocystis rosea $\mathrm{SV} 97^{\mathrm{T}}$ do not possess genes encoding sMMO (Tsien \& Hanson, 1992; McDonald et al., 1997; Lloyd et al., 1999; Wartiainen et al., 2006). The genera Methylocella and Methylocapsa are classified as type II methanotrophs; however, they possess morphological and 
physiological characteristics that are distinctly different from those of other type II methanotrophs (Dedysh et al., 2000, 2002). pMMO has not been observed in Methylocella, for example, and species in this genus have been shown to be facultatively methanotrophic, capable of growing on multicarbon substrates (Dedysh et al., 2005; Theisen \& Murrell, 2005). All Methylocystis species produce oxidase and catalase, are non-motile and are capable of fixing atmospheric nitrogen (Hanson \& Hanson, 1996).

The focus of this paper is strain $\mathrm{CSC}^{\mathrm{T}}$, a type II methanotroph isolated in the mid-1980s from an uncontaminated groundwater aquifer at Moffet Naval Air Station in Mountain View, CA, USA (Henry \& Grbić-Galić, 1990). This methanotroph expresses sMMO under copperlimiting conditions and is capable of oxidizing aliphatic and aromatic compounds (Henry \& Grbić-Galić, 1991; Adriaens, 1994; Adriaens \& Grbić-Galić, 1994; Hršak, 1996; Hršak \& Begonja, 1998). Despite its being the focus of these numerous studies aimed primarily at its contaminant degradation potential, strain $\mathrm{CSCl}^{\mathrm{T}}$ has not been characterized and differentiated from other known type II methanotrophs. This study provides phenotypic and genotypic analysis of this groundwater isolate. The formal taxonomic description of this novel Methylocystis bacterium, strain $\mathrm{CSCl}^{\mathrm{T}}$, is reported. Differences in various characteristics of strain $\mathrm{CSCl}^{\mathrm{T}}$ compared with other known methanotrophs are described, and its unique surface features broaden the observed physiological traits of methanotrophic bacteria.

Strain $\mathrm{CSCl}^{\mathrm{T}}$ was obtained from Dr Dubravka Hršak (Rudjer Boskovic Institute, Zagreb, Croatia) and Methylosinus trichosporium $\mathrm{OB}^{\mathrm{b}} \mathrm{b}^{\mathrm{T}}$ was obtained from Dr Jeremy Semrau (Department of Civil and Environmental Engineering, University of Michigan, Ann Arbor, MI, USA). Methylocystis parvus NCIMB $11129^{\mathrm{T}}\left(=\mathrm{OBBP}^{\mathrm{T}}\right)$ and Methylocystis echinoides NCIMB 13100 were obtained from the NCIMB (Aberdeen, UK). Methylocystis rosea ATCC BAA- $1196^{\mathrm{T}}\left(=\mathrm{SV} 97^{\mathrm{T}}\right)$ was obtained from the American Type Culture Collection. The basal medium used for growth when culturing for sMMO expression was nitrate mineral salts (NMS) medium with no added copper, as described previously (Whittenbury et al., 1970; Lontoh \& Semrau, 1998). Ultrapure water used in all culturing was obtained from a Barnstead NANOpure type I water purification unit (model D4751), which includes a spiral wound ultrafilter and a UV unit. Copper (II) nitrate $\left[\mathrm{Cu}\left(\mathrm{NO}_{3}\right)_{2}\right.$; $10 \mu \mathrm{mol} \mathrm{l}^{-1}$ ] was added to the NMS medium to provide conditions for pMMO expression. Liquid cultures were grown routinely at 250 r.p.m. and $30{ }^{\circ} \mathrm{C}$ in either 50 or $500 \mathrm{ml}$ batches in $250 \mathrm{ml}$ Erlenmeyer or $2800 \mathrm{ml}$ Fernbach flasks, respectively. The flasks were fitted with rubber stoppers (Fisher Scientific) equipped with a resealable glass tube filled with glass wool to allow headspace removal and filling. A portion of the air headspace was removed and refilled with methane of $99.99 \%$ purity (Strate Welding) using a vacuum pump assembly to achieve a headspace concentration of methane of $20 \%(\mathrm{v} / \mathrm{v})$.
For culturing on solid medium, $1.5 \%$ (w/v) Bacto agar (Difco Laboratories) was added to the NMS medium. All plates were incubated in a sealed desiccator, containing anhydrous $\mathrm{CaSO}_{4}$ (Drierite; W. A. Hammond Drierite Company) under an atmosphere of $20 \%$ methane and $80 \%$ air (by volume) at $30{ }^{\circ} \mathrm{C}$, which was refreshed every $4-5$ days. Purity of the cultures was verified by routine streaking on $2 \%(\mathrm{w} / \mathrm{v})$ nutrient agar in ultrapure water.

sMMO expression was verified qualitatively by a naphthalene oxidation assay modified from Brusseau et al. (1990). Four negative controls, autoclaved cells, cells cultured with $10 \mu \mathrm{mol} \mathrm{Cu}\left(\mathrm{NO}_{3}\right)_{2} \mathrm{l}^{-1}$ (for expression of pMMO), cellfree medium and cells that had been subjected to addition of 1-2 ml acetylene gas (a known inhibitor of MMO; Prior \& Dalton, 1985), were included with three live samples of active test culture diluted to an $\mathrm{OD}_{600}$ of 0.2 and transferred to autoclaved $10 \mathrm{ml}$ capped test tubes. Seventy milligrams crushed naphthalene (Sigma) was added to each tube. After incubation at $30{ }^{\circ} \mathrm{C}$ and 250 r.p.m. for a minimum of $1 \mathrm{~h}, 0.1 \mathrm{ml}$ of a freshly prepared solution of $4.21 \mathrm{mmol}$ tetrazotized $o$-dianisidine $1^{-1}$ (Sigma) was added. A subsequent pink-to-purple colour formation in the tubes indicated positive sMMO activity that was verified using UV/Vis spectrophotometry (Fisher Scientific) at $550 \mathrm{~nm}$.

Genomic DNA was isolated from strain $\mathrm{CSCl}^{\mathrm{T}}$, grown to exponential phase, by a standard method (Ausubel et al., 1989). The $16 \mathrm{~S}$ rRNA gene was amplified by PCR using the universal bacterial primers $27 \mathrm{f}$ and 1492r (Lane, 1991). PCR primers used for sMMO were mmoXA ( $5^{\prime}$-ACCAAGGARCARTTCAAG-3') and mmoXB (5'-TGGCACTCRTARCGCTC-3') (Auman et al., 2000); primers for methanol dehydrogenase (MDH) were mxa f1003 (5'-GCGGCACCAACTGGGGCTGGT- $3^{\prime}$ ) and $m x a$ r1561 (5'-GGGCAGCATGAAGGGCTCCC-3') (McDonald \& Murrell, 1997); and primers for pMMO were A189f (5'-GGNGACTGGGACTTCTGG-3') and A682r (5'-GAASGCNGAGAAGAASGC-3') (Holmes et al., 1995).

All PCRs were carried out in a PTC-200 Thermo Cycler (MJ Research) using $25 \mu \mathrm{l}$ reactions and Premix Taq polymerase (Takara). Conditions used for the different primer sets have been described previously (Auman et al., 2000; Costello \& Lidstrom, 1999; Holmes et al., 1995). The PCR amplification products were ligated to vector pCR2.1 (Invitrogen) and transformed to competent Escherichia coli TOP10F' cells according to the vendor's instructions. Plasmid DNA from transformants was isolated and the inserts were sequenced by the Biotechnology Resource Center at Cornell University (Ithaca, NY, USA).

Sequences were compared with previously identified sequences in the NCBI database using BLAST (Altschul et al., 1990). Sequences identified in BLAST and sequences of extant methanotrophs were aligned and adjusted manually with CLUSTAL_X version 1.82 (Thompson et al., 1997). Phylogenetic trees were generated by the neighbour-joining method in CLUSTAL_X and viewed using TreeView (Page, 1996). 
DNA-DNA hybridizations between strain $\mathrm{CSC1}^{\mathrm{T}}$, Methylocystis echinoides NCIMB 13100 and Methylocystis rosea $\mathrm{SV}^{\mathrm{T}}{ }^{\mathrm{T}}$ were performed by the DSMZ (Braunschweig, Germany) using $2 \times$ SSC buffer $(0.3 \mathrm{M} \mathrm{NaCl}, 0.03 \mathrm{M}$ sodium citrate, $\mathrm{pH} 7.0)$ plus $10 \%(\mathrm{v} / \mathrm{v})$ formamide at an optimal renaturation temperature of $68{ }^{\circ} \mathrm{C}$.

Earlier studies reported strain $\mathrm{CSC}^{\mathrm{T}}$ as a Gram-negative, non-motile coccobacillus, possessing an internal membrane structure characteristic of type II methanotrophs (paired membranes inside the periphery of the cell), and forming lipid inclusions (Henry \& Grbić-Galić, 1990, 1991; Hršak \& Begonja, 1998). Fang et al. (2000) concluded that the intact phospholipids of strain $\mathrm{CSC}^{\mathrm{T}}$ clustered within the type II grouping, clearly distinct from groupings of type I methanotrophs. This study extended the previous phenotypic characterization studies by assessing exospore and rosette formation, growth at $37{ }^{\circ} \mathrm{C}$, the presence of a surface (S-) layer, carbon and nitrogen source utilization and lysis by $2 \%(\mathrm{w} / \mathrm{v})$ SDS, all identified by Bowman et al. (1993) or Hanson \& Hanson (1996) as differentiating characteristics among type II methanotrophic species.

Exospore formation was determined with 1- to 2-week-old broth cultures grown as described previously following the methods of Smibert \& Krieg (1981). Five millilitres of culture was transferred in duplicate to fresh NMS medium for controls. A second set of duplicates was heated in a water bath at $80{ }^{\circ} \mathrm{C}$ for $20 \mathrm{~min}$ for pasteurization. Growth was monitored after streaking the controls and treated cultures onto solid NMS plates and incubation (as described previously) for 21 days. Exospores were monitored using light microscopy, also used to determine rosette formation and motility (Norris \& Ribbons, 1971). Growth in liquid culture was monitored using $250 \mathrm{ml}$ nephlos flasks with the same stopper assembly described above and a UV/Vis spectrophotometer (Fisher Scientific) at a wavelength of $600 \mathrm{~nm}$.

Nitrogen and carbon sources were tested using NMS basal medium. To test for alternative nitrogen sources, $\mathrm{KNO}_{3}$ was replaced with $0.1 \%(\mathrm{w} / \mathrm{v})$ anhydrous L-asparagine (MP Biomedicals), L-aspartate (Pfaltz \& Bauer) or L-glutamine (MP Biomedicals) (all shown to support growth of Methylocystis echinoides IMET $10491^{\mathrm{T}}$ and Methylocystis parvus $\mathrm{OBBP}^{\mathrm{T}}$; Bowman et al., 1993) or L-lysine monohydrochloride (Sigma-Aldrich), L-ornithine hydrochloride (MP Biomedicals) or putrescine (MP Biomedicals) (all shown to support growth of Methylosinus trichosporium $\mathrm{OB}^{\mathrm{T}} \mathrm{b}^{\mathrm{T}}$; Bowman et al., 1993). NMS medium with added $\mathrm{KNO}_{3}$ and without a nitrogen source respectively served as a positive and negative control, and the latter control also served as a test for growth in the absence of added nitrogen. To test for alternative carbon sources, $0.2 \%$ (w/v) methylamine hydrochloride (Alfa Aesar), DMSO, methanol or glucose (Fisher Scientific) was added. Over the 30-day test period, flasks were prepared in duplicate and transfers were made to fresh medium supplied with the appropriate nitrogen or carbon source every 4 days.
Growth measurements were performed as described previously.

Lysis by $2 \%(\mathrm{w} / \mathrm{v})$ SDS (Fisher Scientific) was determined by direct microscopic observation using cells harvested at three-quarters-exponential phase. Cells were centrifuged at $2460 \mathrm{~g}$ for $20 \mathrm{~min}$, resuspended in the $2 \%$ SDS stock solution for approximately $2 \mathrm{~h}$ and observed using an oil immersion phase-contrast microscope (Zeiss).

Transmission electron microscopy (TEM) was used to observe cells of strain $\mathrm{CSC}^{\mathrm{T}}$ expressing MMO, lipid inclusions and other fine structural features, including S-layers. Liquid cultures were incubated for 2-3 days and were fixed for $30 \mathrm{~min}$ at room temperature with cacodylate-buffered glutaraldehyde both with and without $0.1 \%$ Alcian blue (Fassel et al., 1992), stained for $30 \mathrm{~min}$ at room temperature with $1 \%$ cacodylate-buffered osmium tetroxide and then stained for $50 \mathrm{~min}$ in $1 \%$ aqueous uranyl acetate. After dehydrating in increasing strengths of ethanol, cells were embedded in both Spurr's and Epon resins (Dykstra, 1993). Thin sections were prepared and stained with lead citrate and examined on a Zeiss EM-10CA transmission electron microscope. Methylocystis echinoides NCIMB 13100 was observed by negative stain using $1 \%$ aqueous uranyl acetate applied to cell suspensions on Formvarcoated grids.

In order to provide evidence that the observed S-layer is glycoprotein, two additional cytochemical approaches were utilized. Images of Alcian blue-stained specimens were compared with those with no Alcian blue in the glutaraldehyde fixative, since Alcian blue stains polysaccharide moieties (Lewis \& Knight, 1977). Secondly, thin Epon sections on Formvar-coated nickel grids were first exposed to $3 \% \mathrm{H}_{2} \mathrm{O}_{2}$ for $15 \mathrm{~min}$ at room temperature to remove osmium and then exposed to $1 \%$ aqueous Pronase solution (Sigma) for $60-90 \mathrm{~min}$ at $35{ }^{\circ} \mathrm{C}$ to remove protein components from the section (Lewis \& Knight, 1977; Monneron \& Bernhard, 1966). Controls included $\mathrm{H}_{2} \mathrm{O}_{2}$ alone and water substituted for the Pronase step.

The phylogenies of the 16S rRNA gene sequences and the pmoA, mmoX and mxaF partial gene sequences of strain $\mathrm{CSC}^{\mathrm{T}}$ and other methanotroph strains, respectively shown in Figs 1 and 2 and Supplementary Fig. S1(a, b) available in IJSEM Online, are consistent with placement of strain $\mathrm{CSCl}^{\mathrm{T}}$ with other known type II methanotrophs. The $16 \mathrm{~S}$ rRNA phylogeny of strain $\mathrm{CSCl}^{\mathrm{T}}$ clearly places it within a branch of the Alphaproteobacteria dominated by Methylocystis species. Determination of sequence similarities revealed that the closest relatives with validly published names were Methylocystis rosea SV97 ${ }^{\mathrm{T}}$ (99\%), Methylocystis parvus $\mathrm{OBBP}^{\mathrm{T}}(97 \%)$ and Methylocystis echinoides IMET $10491^{\mathrm{T}}$ (97\%) (Fig. 1). Lower 16S rRNA gene similarities of 96 and $95 \%$, respectively, were observed between strain $\mathrm{CSCl}^{\mathrm{T}}$ and the Methylosinus type strains Methylosinus sporium NCIMB $11126^{\mathrm{T}}$ and Methylosinus trichosporium $\mathrm{OB}^{\mathrm{T}} \mathrm{b}^{\mathrm{T}}$. The nearest defined neighbours of strain $\mathrm{CSCl}^{\mathrm{T}}$ are Methylocystis sp. IMET 10486 and two uncultured 


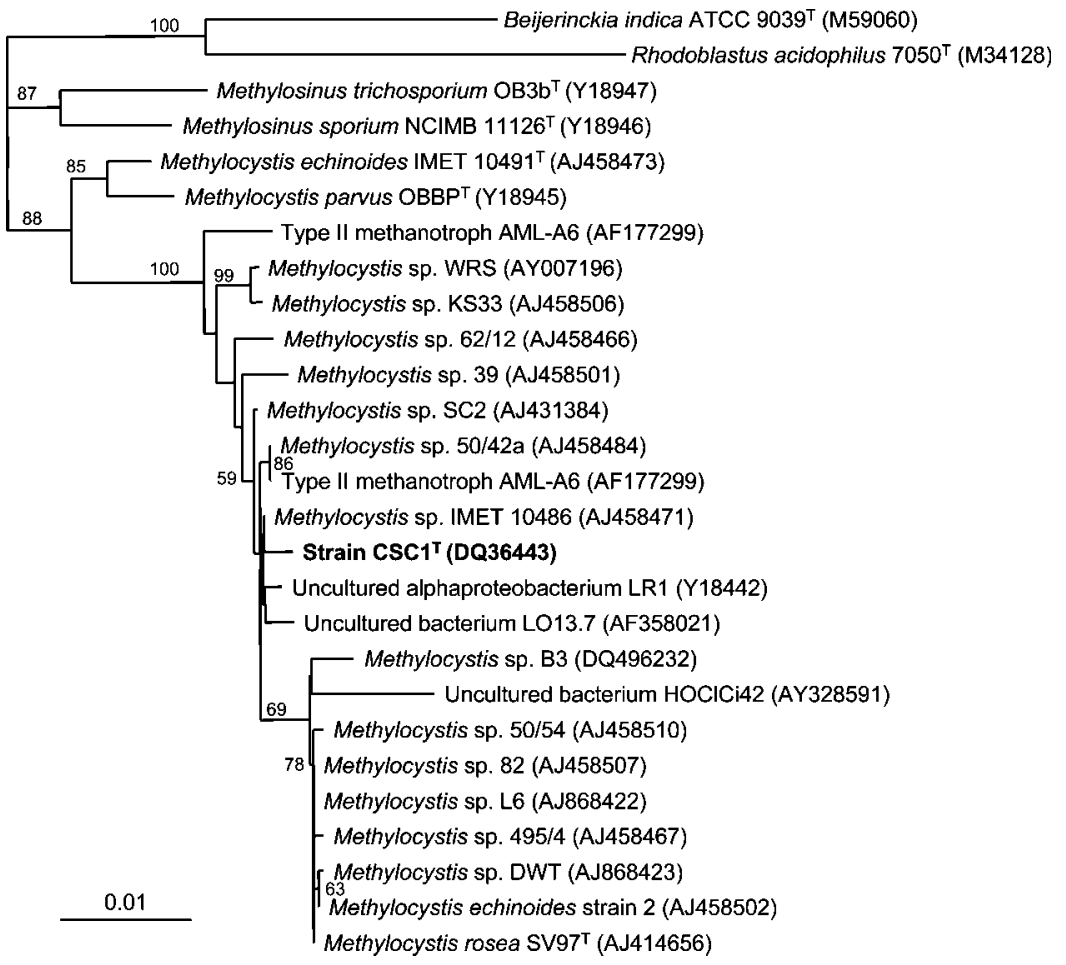

Fig. 1. Phylogenetic relationship of the $16 \mathrm{~S}$ rRNA gene sequences of strain $\mathrm{CSC}^{\top}$ and other type II methanotrophs and related strains. The dendrogram shows the results of an analysis in which neighbour-joining was used. Numbers on branches represent bootstrap percentages greater than $50 \%$, derived from 1000 replicates. Bar, 0.01 substitutions per nucleotide site. 16S rRNA gene sequences from two non-methanotrophic alphaproteobacteria were used as an outgroup.

members of the Methylocystaceae (LR1 and LO13.7), each sharing $99 \% 16 \mathrm{~S}$ rRNA gene sequence similarity with strain $\mathrm{CSCl}^{\mathrm{T}}$. The greatest similarity of the partial $p m o A$ gene sequence of strain $\mathrm{CSCl}^{\mathrm{T}}$ was observed with various uncultured bacteria [uncultured bacterium DGGE band P5 (99\%), LOPB13.1 (99\%) and SL-1.52 (98\%)] (Fig. 2). Those strains from species with validly published names most closely matching the $p m o A$ partial gene sequence of

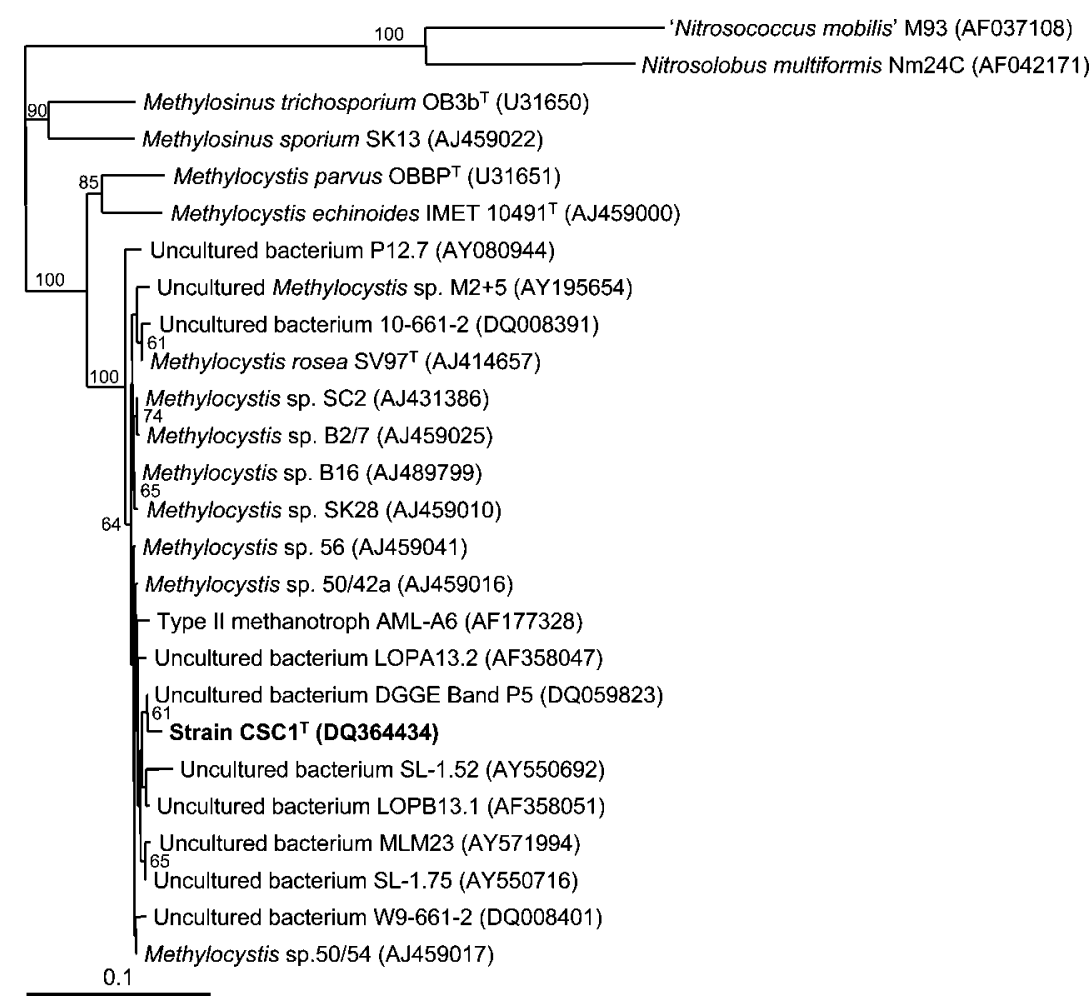

Fig. 2. Phylogenetic relationship of the partial pmo $A$ gene sequences of strain $\mathrm{CSC}^{\top}{ }^{\top}$ and members of related genera. Numbers on branches represent bootstrap percentages greater than $50 \%$, derived from 1000 replicates. Bar, 0.1 substitutions per nucleotide site. $a m o A$ sequences of two ammoniaoxidizing bacteria were used as an outgroup. 
strain $\mathrm{CSC}^{\mathrm{T}}$ were again Methylocystis rosea $\mathrm{SV}^{\mathrm{T}}{ }^{\mathrm{T}}(98 \%)$, Methylocystis echinoides IMET $10491^{\mathrm{T}}(92 \%)$ and Methylocystis parvus $\mathrm{OBBP}^{\mathrm{T}}(92 \%)$.

Given the suspected placement in the genus Methylocystis, DNA-DNA hybridization was performed with Methylocystis echinoides NCIMB 13100 and Methylocystis rosea SV97 ${ }^{\mathrm{T}}$, yielding relatedness values of 3.8 and $41.1 \%$, respectively. Strain $\mathrm{CSC}^{\mathrm{T}}$ therefore does not belong to the species Methylocystis echinoides or Methylocystis rosea, according to the $70 \%$ threshold value recommendation of Wayne et al. (1987).

As shown in Table 1, rosette formation by cells of strain $\mathrm{CSC}^{\mathrm{T}}$ was not observed. No growth was evident after pasteurization, indicating that this methanotroph is not resistant to heat, and growth was also not observed at $37^{\circ} \mathrm{C}$. Optimum growth was observed at approximately $30{ }^{\circ} \mathrm{C}$. As reported previously for Methylosinus trichosporium OB3b ${ }^{\mathrm{T}}$, Methylocystis echinoides IMET $10491^{\mathrm{T}}$ and Methylocystis parvus $\mathrm{OBBP}^{\mathrm{T}}$ (Bowman et al., 1993), strain $\mathrm{CSC1}^{\mathrm{T}}$ was not lysed by a $2 \%$ solution $(\mathrm{w} / \mathrm{v})$ of SDS, but $10 \%(\mathrm{w} / \mathrm{v})$ SDS did lyse the cells. It was shown to be capable of growing on alternative nitrogen sources
L-asparagine, L-aspartate, L-glutamine, L-ornithine and putrescine; however, no growth was visible in the presence of L-lysine. Growth was also observed in nitrogen-free NMS medium. As reported for Methylosinus trichosporium $\mathrm{OB}^{\mathrm{T}} \mathrm{b}^{\mathrm{T}}$, Methylocystis echinoides IMET $10491^{\mathrm{T}}$ and Methylocystis parvus $\mathrm{OBBP}^{\mathrm{T}}$ by Bowman et al. (1993), of the four alternative carbon sources methylamine, dimethylsulfide, methanol and glucose tested, only methanol supported growth of strain $\mathrm{CSCl}^{\mathrm{T}}$.

Expression of sMMO upon culturing strain $\mathrm{CSCl}^{\mathrm{T}}$ in NMS medium with no copper was confirmed by formation of a purple colour after incubation with naphthalene and addition of $o$-dianisidine, whereas controls with acetylene and with cells cultured in the presence of copper yielded no colour. These results strongly suggest that sMMO was expressed in strain $\mathrm{CSC}_{1}{ }^{\mathrm{T}}$ when grown without copper and was responsible for the naphthalene oxidation.

TEMs of strain $\mathrm{CSCl}^{\mathrm{T}}$ grown in the presence of copper verify the type II membrane structure of paired membrane lamellae in the peripheral cytoplasm (Fig. 3a, b). In thin section, a variety of cell shapes were visible at low magnification (Fig. 3a), but elongated or dumbbell shapes

Table 1. Phenotypic characteristics that differentiate strain $\mathrm{CSC} 1^{\top}$ from related type strains

Strains: 1, strain $\operatorname{CSC1}^{\mathrm{T}}$ (unless indicated, data obtained from Henry \& Grbić-Galić, 1990, 1991; Hršak \& Begonja, 1998); 2, Methylosinus trichosporium $\mathrm{OB}^{\mathrm{T}} \mathrm{b}^{\mathrm{T}}$ (Whittenbury et al., 1970; Fassel et al., 1990, 1992; Bowman et al., 1993; Hanson \& Hanson, 1996); 3, Methylocystis echinoides IMET $10491^{\mathrm{T}}$ (Gal'chenko et al., 1977; Bowman et al., 1993; Hanson \& Hanson, 1996); 4, Methylocystis parvus OBBP $^{\mathrm{T}}$ (Whittenbury et al., 1970; Bowman et al., 1993; Hanson \& Hanson, 1996).

\begin{tabular}{|c|c|c|c|c|}
\hline Characteristic & 1 & 2 & 3 & 4 \\
\hline Colony colour & Cream & White/buff/yellow & White/buff/pale pink & White/tan/pale pink \\
\hline \multicolumn{5}{|l|}{ Cell morphology } \\
\hline Length $(\mu \mathrm{m})$ & $0.7-1$ & $2-3$ & $0.8-1.2$ & $0.5-1.5$ \\
\hline Shape & Dumbbell & Pear & Coccobacillus, rod & Coccobacillus \\
\hline S-layers & Sharp, solid spines ${ }^{*}$ & Bead-like/filamentous & Tubular spines & - \\
\hline Polyphosphate & $+^{*}$ & - & - & + \\
\hline PHB & + & + & $-\dagger$ & + \\
\hline Motility & - & Polar flagella & - & - \\
\hline Rosettes & $-*$ & + & - & - \\
\hline Heat resistance & $-{ }^{*}$ & + & - & - \\
\hline Growth at $37{ }^{\circ} \mathrm{C}$ & $-*$ & + & $-\dagger$ & + \\
\hline L-Lysine & $-{ }^{*}$ & + & - & $+\ddagger$ \\
\hline L-Ornithine & $+^{*}$ & + & - & $+\ddagger$ \\
\hline Putrescine & $+^{\star}$ & + & - & $+\ddagger$ \\
\hline
\end{tabular}

${ }^{*}$ Data from this study.

$\dagger$ Contrary to the reported characteristics of Methylocystis echinoides IMET 10491 ${ }^{\mathrm{T}}$ (Bowman et al., 1993), our experiments showed Methylocystis echinoides NCIMB 13100 to accumulate PHB and to grow at $37{ }^{\circ} \mathrm{C}$.

$\$$ Bowman et al. (1993) reported $75-87 \%$ of strains positive. 


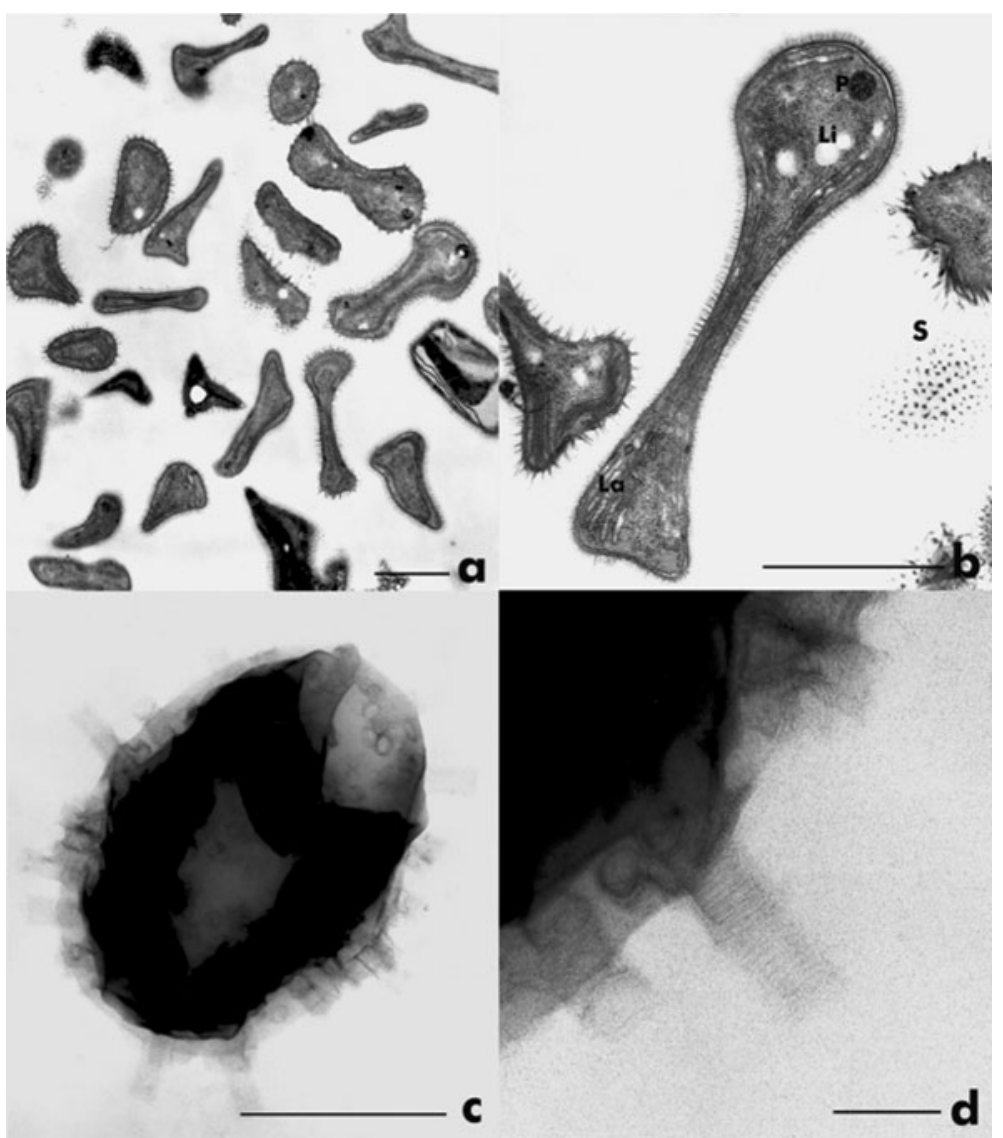

Fig. 3. Transmission electron micrographs of strain $\operatorname{CSC}^{\top}(a, b)$ and Methylocystis echinoides NCIMB 13100 (c, d). (a, b) Morphology of cells of strain $\mathrm{CSC}_{1}{ }^{\top}$ grown with $10 \mu \mathrm{M}$ copper. In (b), numerous lamellae (La) are present. Lipid inclusions $(\mathrm{Li})$ and polyphosphate $(P)$ storage inclusions are also present. $S$ indicates a surface view of the spiny surface of a cell. (c, d) Cells of Methylocystis echinoides NCIMB 13100 viewed with negative stain are elliptical in profile and have numerous tubular projections from the surface. In (c), some may be seen in circular end-on profile at the upper right. The high-magnification view (d) shows that the tubes are striated. Bars, $1 \mu \mathrm{m}$ (a and b), $0.5 \mu \mathrm{m}$ (c) and $0.1 \mu \mathrm{m}$ (d).

of cells predominated. Many of the other profiles could represent dumbbell shapes sectioned in different planes. Cells grown without copper contained only a few internal membranous lamellae (data not shown). Polyphosphate bodies and lipid inclusions were common.

As shown in Fig. 3(a, b), distinctive S-layers, probably composed of glycoprotein, were revealed with TEM of ultrathin sections of strain $\mathrm{CSCl}^{\mathrm{T}}$ fixed with Alcian blue. These spiked S-layer structures, $50-75 \mathrm{~nm}$ in height, covered the entire surface of the cell wall. We have seen that the cytoplasm of cells of strain $\mathrm{CSCl}^{\mathrm{T}}$ embedded in Spurr resin will sometimes shrink away from the wall, lending support to the idea that the S-layer is more rigid than the rest of the wall (data not shown). This shrinkage does not occur in cells embedded in Epon resin (e.g. cells in Fig. 3a, b).

S-layers have been observed in both type I and II methanotrophs isolated from a wide range of environments, including members of the genera Methylomicrobium, Methylomonas, Methylosinus and Methylocystis (Fassel et al., 1992; Sorokin et al., 2000; Trotsenko \& Khmelenina, 2002). Type II Methylosinus trichosporium $\mathrm{OB} 3 \mathrm{~b}^{\mathrm{T}}$ was found to have bead-like S-layer structures and occasional filamentous material in the outer envelope (Fassel et al. 1990, 1992). Similar bead-like S-layer structures were observed by Fassel et al. (1992) in the cell envelope of Methylocystis sp. strain Lake Washington, but not in a strain the authors referred to as 'Methylocystis paris', and the authors concluded that the absence of these structures in the latter species could be a species variation. Both Methylocystis species possessed considerable filamentous material, however (Fassel et al., 1992). Methylocystis echinoides was reported to have rigid tubular structures arranged radially at the cell surface (Gal'chenko et al., 1977), features that are absent from Methylocystis parvus $\mathrm{OBBP}^{\mathrm{T}}$ (Heyer et al., 2002). In this study, negative-stain preparations of Methylocystis echinoides NCIMB 13100 show ellipsoid cells with square-ended tubular projections (Fig. 3c) that appear striated at high magnification (Fig. 3d), as reported by Haubold (1977) for this strain but not in the original description of Gal'chenko et al. (1977). Haubold (1977) concluded that the tubes of Methylocystis echinoides IMET $10491^{\mathrm{T}}$ were smaller in diameter than those described by Gal'chenko et al. (1977). The tubular appearance of the S-layers of Methylocystis echinoides NCIMB 13100 (Fig. 3c, d) and the isolate described by Gal'chenko et al. (1977) is considerably different from the solid-sharp spines of strain $\mathrm{CSC1}^{\mathrm{T}}$.

To elucidate further the nature of the spiked S-layer in strain $\mathrm{CSCl}^{\mathrm{T}}$, cells fixed with glutaraldehyde alone (Supplementary Fig. S2a) were compared with those fixed with an Alcian blue/glutaraldehyde mixture 
(Supplementary Fig. S2b). Alcian blue is a differential stain for polysaccharide (Lewis \& Knight, 1977), and the spines visible in Supplementary Fig. S2(b) were considerably darker, longer and more distinct than the same structures visible in Supplementary Fig. S2(a), even though Supplementary Fig. S2(b) is at a lower magnification. This strongly indicates polysaccharide content. After treatment with $\mathrm{H}_{2} \mathrm{O}_{2}$ to remove osmium from the Epon sections, sections treated with Pronase, a broad-spectrum protease, lost the entire S-layer (Supplementary Fig. S2c, d), indicating that the layer contains considerable protein.

Sequence analysis of the $16 \mathrm{~S}$ rRNA gene (Fig. 1) and partial gene sequences of $p m o A$ (Fig. 2), mmoX (Supplementary Fig. S1a) and mxaF (Supplementary Fig. S1b) supports placement of strain $\mathrm{CSCl}^{\mathrm{T}}$ within the closely related genera Methylocystis and Methylosinus. Phenotypic results (Table 1) show that strain $\mathrm{CSCl}^{\mathrm{T}}$ can be differentiated from Methylosinus trichosporium $\mathrm{OB}^{\mathrm{b}} \mathrm{b}^{\mathrm{T}}$, Methylocystis echinoides IMET $10491^{\mathrm{T}}$ and Methylocystis parvus $\mathrm{OBBP}^{\mathrm{T}}$. All of the strains included in Table 1 have been reported to be oxidase- and catalase-positive, possess colonies that are of opaque transparency, smooth edge and convex elevation and grow on methanol and in nitrogen-free medium. Unlike the known strains, strain $\mathrm{CSC}^{\mathrm{T}}$ was not capable of growth at $37{ }^{\circ} \mathrm{C}$; however, all of the methanotrophs grow optimally near $30^{\circ} \mathrm{C}$. Unlike Methylocystis echinoides IMET $10491^{\mathrm{T}}$, strain $\mathrm{CSCl}^{\mathrm{T}}$ was observed to accumulate poly- $\beta$ hydroxybutyrate (PHB). Gal'chenko et al. (1977) reported the ability of their isolate to accumulate $\mathrm{PHB}$ and grow at $37^{\circ} \mathrm{C}$, whereas Bowman et al. (1993) reported that Methylocystis echinoides IMET $10491^{\mathrm{T}}$ did not accumulate PHB or grow at $37{ }^{\circ} \mathrm{C}$. Our TEM and growth studies using Methylocystis echinoides NCIMB 13100 agree with the results of Gal'chenko et al. (1977) (data not shown), suggesting that Methylocystis echinoides strains NCIMB 13100 and IMET $10491^{\mathrm{T}}$ in fact belong to different species.

The elongated dumbbell shape of strain $\mathrm{CSC1}^{\mathrm{T}}$, its lack of motility and its ability to form polyphosphate separate it from Methylosinus trichosporium $\mathrm{OB}^{\mathrm{b}} \mathrm{b}^{\mathrm{T}}$. Other distinguishing characteristics between strain $\mathrm{CSCl}^{\mathrm{T}}$ and Methylosinus trichosporium $\mathrm{OB}^{2} \mathrm{~b}^{\mathrm{T}}$ include smaller cell size, S-layer morphology and lack of heat resistance. Also, unlike reported observations of Methylosinus trichosporium $\mathrm{OB}^{2} \mathrm{~b}^{\mathrm{T}}$, strain $\mathrm{CSC}^{\mathrm{T}}$ can use L-asparagine, L-aspartate and L-glutamine and cannot use L-lysine as a nitrogen source. The two strains share the ability to use L-ornithine and putrescine.

Greater similarity, however, is shared with the two Methylocystis strains, including the absence of motility, heat resistance and rosette formation. The cell shape of strain $\mathrm{CSCl}^{\mathrm{T}}$, its ability to form polyphosphate and its cream-coloured colonies differ from Methylocystis echinoides IMET $10491^{\mathrm{T}}$ and Methylocystis parvus $\mathrm{OBBP}^{\mathrm{T}}$ (Table 1). Unlike Methylocystis echinoides IMET $10491^{\mathrm{T}}$, strain $\mathrm{CSC}^{\mathrm{T}}$ is capable of using L-ornithine and putrescine as nitrogen sources, whereas, unlike Methylocystis parvus
$\mathrm{OBBP}^{\mathrm{T}}$, strain $\mathrm{CSCl}^{\mathrm{T}}$ is not capable of using L-lysine. In addition, as reported for Methylocystis trichosporium $\mathrm{OB}^{\mathrm{T}} \mathrm{b}^{\mathrm{T}}$, Methylocystis echinoides IMET $10491^{\mathrm{T}}$ and Methylocystis parvus $\mathrm{OBBP}^{\mathrm{T}}$, cells of strain $\mathrm{CSCl}^{\mathrm{T}}$ are not lysed by $2 \%(\mathrm{w} / \mathrm{v})$ SDS.

While strain $\mathrm{CSCl}^{\mathrm{T}}$ has previously been shown by TEM to contain characteristic type II membranes (Henry \& GrbićGalić, 1990; Hršak \& Begonja, 1998), it was revealed here to accumulate both polyphosphate bodies (Fig. 2) and PHB storage granules, consistent with the properties of Methylocystis parvus $\mathrm{OBBP}^{\mathrm{T}}$ (Bowman et al., 1993). No study has reported the structure of the cell envelope of strain $\mathrm{CSC}^{\mathrm{T}}$ in comparison with that of other well-characterized methanotrophs. Of special interest are the S-layers, regular crystalline surface layers in archaea and bacteria, composed of protein or glycoprotein subunits (Sleytr et al., 1993; Sidhu \& Olsen, 1997).

It is not known why S-layers develop in some bacteria and not in other closely related strains. However, hypotheses include suggestions that formation of these structures reflects adaptation to an ecological niche (Easterbrook \& Alexander, 1983; Easterbrook, 1989) or a response to exposure to harsh environments (Minsky et al., 2002). Others suggest that S-layers may provide micro-organisms with a selective advantage by serving as a protective coating or as molecular porins or sieves and traps for substrates, in maintaining the rigidity of the cell envelope or in providing a means of cell adhesion and surface recognition (Sára \& Sleytr, 1987; Sleytr \& Messner, 1988; Sára et al., 1992; Sidhu \& Olsen, 1997). Easterbrook \& Sperker (1982) hypothesized that spinae may simultaneously fulfil many fortuitous roles, analogous to 'arms' with multipotential activities, including attachment, distance-keeping and protection. However, why some species are prone to spine formation and others are not, why S-layers exist in a variety of shapes and symmetries and why these structures develop among species of methanotrophs is not clearly understood.

The original report of Gal'chenko et al. (1977) referred to an isolate from lake mud in Russia, whereas the type strain Methylocystis echinoides IMET $10491^{\mathrm{T}}$ was isolated from sewage sludge (Meyer et al., 1986), both more nutrient-rich environments than the sediments of the uncontaminated groundwater aquifer in California where strain $\mathrm{CSCl}^{\mathrm{T}}$ was isolated. The epithet echinoides is a Neo-Latin adjective derived from the Greek word echinos, meaning hedgehog, named for the hedgehog-like appearance of this bacterium. However, as reported by Gal'chenko et al. (1977) and Haubold (1977) and verified in this study (Fig. 3c, d), the spines on these methanotrophs appear to be tubular and less dense in comparison with the spikes observed on strain $\mathrm{CSCl}^{\mathrm{T}}$, which would be more aptly named for a hedgehog. Despite the different originating environments of Methylocystis echinoides IMET $10491^{\mathrm{T}}$ and strain $\mathrm{CSC}^{\mathrm{T}}$, proximity in the grouping of the genus Methylocystis, as strongly suggested by the results of this study, adds credence to the hypothesis that phylogeny and ecology may both play a 
role in S-layer formation. Similar clustering of S-layerproducing strains of Bacillus cereus has been observed and, similar to these results, some strains in this cluster do not possess S-layers, while others do (Mignot et al., 2001). These authors concluded that ecological pressure is associated with the acquisition and maintenance of S-layers in hosts that fall into a phylogenetic cluster.

Phylogenetically, strain $\mathrm{CSCl}^{\mathrm{T}}$ is most closely related to Methylocystis species. Its cell size, rosette formation and presence of surface layers are most similar to Methylocystis echinoides IMET $10491^{\mathrm{T}}$. However, DNA-DNA hybridization revealed only $3.8 \%$ relatedness between strain $\mathrm{CSC}^{\mathrm{T}}$ and Methylocystis echinoides NCIMB 13100 and $41.1 \%$ relatedness with Methylocystis rosea SV97 ${ }^{\mathrm{T}}$. Strain $\mathrm{CSC}^{\mathrm{T}}$ and Methylocystis echinoides IMET $10491^{\mathrm{T}}$ showed differences in surface-layer morphology, cell shape, colony colour, formation of polyphosphate and ability to use L-ornithine or putrescine as a nitrogen source. Characteristics of cell shape and the presence of surface layers, genes encoding sMMO and the ability to use L-lysine as a nitrogen source are divergent from Methylocystis parvus $\mathrm{OBBP}^{\mathrm{T}}$. The lack of polar flagella, smaller cell size, different cell shape, lack of heat resistance, presence of polyphosphate, ability to use L-asparagine, L-aspartate or L-glutamine and inability to use L-lysine as a nitrogen source differentiate strain $\mathrm{CSCl}^{\mathrm{T}}$ from Methylosinus trichosporium $\mathrm{OB} 3 \mathrm{~b}^{\mathrm{T}}$. Accepting these differences, strain $\mathrm{CSCl}^{\mathrm{T}}$ could be described as a member of a novel species in the genus Methylocystis.

\section{Description of Methylocystis hirsuta sp. nov.}

Methylocystis hirsuta (hir.su'ta. L. fem. adj. hirsuta hairy, rough, shaggy, bristly).

Cells are aerobic, Gram-negative, $0.3-0.6 \times 0.7-1 \mu \mathrm{m}$ in size and occur singly or in clusters. Reproduces by normal cell division; budding division does not occur. Cells are not motile but possess a spiny surface layer composed of polysaccharide. Produces oxidase and catalase. Forms lipid cysts. PHB accumulates. Contains type II intracytoplasmic membranes which are aligned parallel to the cell wall. Type II methanotroph. Methane and methanol are the sole sources of carbon and energy. Capable of using $\mathrm{KNO}_{3}$, L-asparagine, L-aspartate, L-glutamine, L-ornithine and putrescine. Capable of growth in nitrogen-free medium. Expresses sMMO under low copper concentrations. Capable of cometabolically oxidizing a variety of aliphatic and aromatic compounds. Not resistant to pasteurization. Is not lysed by $2 \%(\mathrm{w} / \mathrm{v})$ SDS, but is lysed by $10 \%(\mathrm{w} / \mathrm{v})$ SDS. Colonies are cream-coloured, slow-growing and 0.8$1.5 \mathrm{~mm}$ in diameter after $17-18$ days at $30{ }^{\circ} \mathrm{C}$ on NMS agar plates, incubated in the presence of $20 \%(\mathrm{v} / \mathrm{v})$ methane in the headspace of a sealed desiccator. No growth on complex organic media. Optimal $\mathrm{pH}$ for growth is 7.0 ; does not grow at $\mathrm{pH} 4.0$ or 9.0 . Is not capable of growth at $37^{\circ} \mathrm{C}$. Optimal temperature for growth is approximately $30{ }^{\circ} \mathrm{C}$.
The type strain, strain $\mathrm{CSC}^{\mathrm{T}}\left(=\mathrm{ATCC}\right.$ BAA- $1344^{\mathrm{T}}=\mathrm{DSM}$ $18500^{\mathrm{T}}$ ), was isolated from an uncontaminated groundwater aquifer in the mid-1980s from Moffett Naval Air Station in Mountain View, CA, USA.

\section{Acknowledgements}

The authors wish to thank Dr Dubravka Hršak for donation of strain $\mathrm{CSCl}^{\mathrm{T}}$ and Dr Jeremy Semrau for donation of Methylosinus trichosporium $\mathrm{OB}^{\mathrm{T}} \mathrm{b}^{\mathrm{T}}$ used in this work. We gratefully acknowledge Dr Andrew Ogram of the Soil and Water Science Department at UF for his generosity of time, lab space and resources during the initial phases of this work. We particularly wish to lovingly acknowledge the life and career of gentleman-scholar Dr Henry Aldrich (deceased 9 August 2005), our mentor and role model.

\section{References}

Adriaens, P. (1994). Evidence for chlorine migration during oxidation of 2-chlorobiphenyl by a type II methanotroph. Appl Environ Microbiol 60, 1658-1662.

Adriaens, P. \& Grbić-Galić, D. (1994). Cometabolic transformation of mono- and dichlorobiphenyls and chlorohydroxybiphenyls by methanotrophic groundwater isolates. Environ Sci Technol 28, 1325-1330.

Altschul, S. F., Gish, W., Miller, W., Myers, E. W. \& Lipman, D. J. (1990). Basic local alignment search tool. J Mol Biol 215, 403-410.

Auman, A. J., Stolyar, S., Costello, A. M. \& Lidstrom, M. E. (2000). Molecular characterization of methanotrophic isolates from freshwater lake sediment. Appl Environ Microbiol 66, 5259-5266.

Ausubel, F. M., Brent, R., Kingston, R. E., Moore, D. D., Smith, J. A., Seidman, J. G. \& Struhl, K. (editors) (1989). Current Protocols in Molecular Biology. New York: Wiley.

Bowman, J. P., Sly, L. I., Nichols, P. D. \& Hayward, A. C. (1993). Revised taxonomy of the methanotrophs: description of Methylobacter gen. nov., emendation of Methylococcus, validation of Methylosinus and Methylocystis species and a proposal that the family Methylococcaceae includes only the group I methanotrophs. Int J Syst Bacteriol 43, 735-753.

Brusseau, G. A., Tsien, H. C., Hanson, R. S. \& Wackett, L. P. (1990). Optimization of trichloroethylene oxidation by methanotrophs and the use of a colorimetric assay to detect soluble methane monooxygenase activity. Biodegradation 1, 19-29.

Calhoun, A. \& King, G. M. (1998). Characterization of root-associated methanotrophs from three freshwater macrophytes: Pontederia cordata, Sparganium eurycarpum, and Sagittaria latifolia. Appl Environ Microbiol 64, 1099-1105.

Choi, D.-W., Kunz, R. C., Boyd, E. S., Semrau, J. D., Antholine, W. A., Han, J.-I., Zahn, J. A., Boyd, J. M., de la Mora, A. M. \& DiSpirito, A. A. (2003). The membrane-associated methane monooxygenase (pMMO) and pMMO-NADH: quinone oxidoreductase complex from Methylococcus capsulatus Bath. J Bacteriol 185, 5755-5764.

Costello, A. M. \& Lidstrom, M. E. (1999). Molecular characterization of functional and phylogenetic genes from natural populations of methanotrophs in lake sediments. Appl Environ Microbiol 65, 5066-5074.

Dedysh, S. N., Liesack, W., Khmelenina, V. N., Suzina, N. E., Trotsenko, Y. A., Semrau, J. D., Bares, A. M., Panikov, N. S. \& Tiedje, J. M. (2000). Methylocella palustris gen. nov., sp. nov., a new methaneoxidizing acidophilic bacterium from peat bogs, representing a novel subtype of serine-pathway methanotrophs. Int J Syst Evol Microbiol 50, 955-969. 
Dedysh, S. N., Khmelenina, V. N., Suzina, N. E., Trotsenko, Y. A., Semrau, J. D., Liesack, W. \& Tiedje, J. M. (2002). Methylocapsa acidiphila gen. nov., sp. nov., a novel methane-oxidizing and dinitrogen-fixing acidophilic bacterium from Sphagnum bog. Int $J$ Syst Evol Microbiol 52, 251-261.

Dedysh, S. N., Knief, C. \& Dunfield, P. F. (2005). Methylocella species are facultatively methanotrophic. J Bacteriol 187, 4665-4670.

Dykstra, M. J. (1993). Manual of Applied Techniques for Biological Electron Microscopy. New York: Plenum.

Easterbrook, K. B. (1989). Spinate bacteria. In Bergey's Manual of Systematic Bacteriology, vol. 3, pp. 1991-1993. Edited by J. T. Staley, M. P. Bryant, N. Pfennig \& J. G. Holt. Baltimore: Williams \& Wilkins.

Easterbrook, K. B. \& Alexander, S. A. (1983). The initiation and growth of bacterial spinae. Can J Microbiol 29, 476-487.

Easterbrook, K. B. \& Sperker, S. (1982). Physiological controls of bacterial spinae production in complex medium and their value as indicators of spina function. Can J Microbiol 28, 130-136.

Fang, J., Barcelona, M. \& Semrau, J. (2000). Characterization of methanotrophic bacteria on the basis of intact phospholipid profiles. FEMS Microbiol Lett 189, 67-72.

Fassel, T. A., Schaller, M. J., Lidstrom, M. E. \& Remsen, C. C. (1990). Effect of fixation-resin combinations and ruthenium red on elucidating outer envelope structure and surface morphology of two methanotrophic bacteria. J Electron Microsc Tech 14, 52-62.

Fassel, T. A., Schaller, M. J. \& Remsen, C. C. (1992). Comparison of Alcian blue and ruthenium red effects on preservation of outer envelope ultrastructure in methanotrophic bacteria. Microsc Res Tech 20, 87-94.

Gal'chenko, V. F., Shishkina, V. N., Suzina, N. E. \& Trotsenko, Y. A. (1977). Isolation and properties of new strains of obligate methanotrophs. Mikrobiologiia 46, 723-728 (in Russian).

Graham, D., Kim, H. Y. \& Lindner, A. S. (2002). Methanotrophic bacteria. In Encyclopedia of Environmental Microbiology, pp. 1923-1936. Edited by G. Bitton. New York: Wiley.

Hanson, R. S. \& Hanson, T. E. (1996). Methanotrophic bacteria. Microbiol Rev 60, 439-471.

Haubold, R. (1977). Two different types of surface structures of methane utilizing bacteria. Z Allg Mikrobiol 18, 511-515.

Henry, S. M. \& Grbić-Galić, D. (1990). Effect of mineral media on trichloroethylene oxidation by aquifer methanotrophs. Microb Ecol 20, 151-169.

Henry, S. M. \& Grbić-Galić, D. (1991). Influence of endogenous and exogenous electron donors and trichloroethylene oxidation toxicity on trichloroethylene oxidation by methanotrophic cultures from a groundwater aquifer. Appl Environ Microbiol 57, 236-244.

Heyer, J., Gal'chenko, V. \& Dunfield, P. F. (2002). Molecular phylogeny of type II methane-oxidizing bacteria isolated from various environments. Microbiology 148, 2831-2846.

Holmes, A. J., Costello, A., Lidstrom, M. E. \& Murrell, J. C. (1995). Evidence that particulate methane monooxygenase and ammonia monooxygenase may be evolutionarily related. FEMS Microbiol Lett 132, 203-208.

Hršak, D. (1996). Cometabolic transformation of linear alkylbenzenesulphonates by methanotrophs. Water Res 30, 3092-3098.

Hršak, D. \& Begonja, A. (1998). Growth characteristics and metabolic activities of the methanotrophic-heterotrophic groundwater community. J Appl Microbiol 85, 448-456.

Lane, D. J. (1991). 16S/23S rRNA sequencing. In Nucleic Acid Techniques in Bacterial Systematics, pp. 115-175. Edited by E. Stackebrandt \& M. Goodfellow. New York: Wiley.
Lewis, P. R. \& Knight, D. P. (1977). Staining Methods for Sectioned Material. Amsterdam: North-Holland.

Lloyd, J. S., DeMarco, P., Dalton, H. \& Murrell, J. C. (1999). Heterologous expression of soluble methane monooxygenase genes in methanotrophs containing only particulate methane monooxygenase. Arch Microbiol 171, 364-370.

Lontoh, S. \& Semrau, J. D. (1998). Methane and trichloroethylene degradation by Methylosinus trichosporium OB3b expressing particulate methane monooxygenase. Appl Environ Microbiol 64, 1106-1114.

McDonald, I. R. \& Murrell, J. C. (1997). The methanol dehydrogenase structural gene $m x a F$ and its use as a functional gene probe for methanotrophs and methylotrophs. Appl Environ Microbiol 63, 3218-3224.

McDonald, I. R., Uchiyama, H., Kame, S., Yagi, O. \& Murrell, J. C. (1997). The soluble methane monooxygenase gene cluster of the trichloroethylene-degrading methanotroph Methylocystis sp. strain M. Appl Environ Microbiol 63, 1898-1904.

Meyer, J., Haubold, J., Heyer, J. \& Bökel, W. (1986). Contribution to the taxonomy of methanotrophic bacteria: correlation between membrane type and GC-value. J Basic Microbiol 26, 155-160.

Mignot, T., Denis, B., Couture-Tosi, E., Kolsto, A.-B., Mock, M. \& Fouet, A. (2001). Distribution of S-layers on the surface of Bacillus cereus strains: phylogenetic origin and ecological pressure. Environ Microbiol 3, 493-501.

Minsky, A., Shimoni, E. \& Frenkiel-Krispin, D. (2002). Stress, order and survival. Nat Rev Mol Cell Biol 3, 50-60.

Monneron, A. \& Bernhard, W. (1966). Action de certaines enzymes sur des tissus inclus en Epon. J Microsc 5, 697-714 (in French).

Murrell, J. C. \& Radejewski, S. (2000). Cultivation-independent techniques for studying methanotroph ecology. Res Microbiol 151, 807-814.

Norris, J. R. \& Ribbons, D. W. (editors) (1971). Methods in Microbiology, vol. 6A. London: Academic Press.

Page, R. D. M. (1996). TreeView: an application to display phylogenetic trees on personal computers. Comput Appl Biosci 12, 357-358.

Prior, S. D. \& Dalton, H. (1985). Acetylene as a suicide substrate and active site probe for methane monooxygenase from Methylococcus capsulatus (Bath). FEMS Microbiol Lett 29, 105-109.

Sára, M. \& Sleytr, U. B. (1987). Molecular sieving through S-layers of Bacillus stearothermophilus strains. J Bacteriol 169, 4092-4098.

Sára, M., Pum, D. \& Sleytr, U. B. (1992). Permeability and chargedependent adsorption properties of the S-layer lattice from Bacillus coagulans E36-66. J Bacteriol 174, 3487-3493.

Sidhu, M. S. \& Olsen, I. (1997). S-layers of Bacillus species. Microbiology 143, 1039-1052.

Sleytr, U. B. \& Messner, P. (1988). Crystalline surface layers in prokaryotes. J Bacteriol 170, 2891-2897.

Sleytr, U. B., Messner, P., Pum, D. \& Sara, M. (1993). Crystalline bacterial cell surface layers: general principles and application potential. J Appl Bacteriol 74, S21-S32.

Smibert, R. M. \& Krieg, N. R. (1981). General characterization. In Manual of Methods for General Bacteriology, pp. 409-443. Edited by G. B. Phillips. Washington, DC: American Society for Microbiology.

Sorokin, D. Y., Jones, B. E. \& Kuenen, J. G. (2000). An obligate methylotrophic, methane-oxidizing Methylomicrobium species from a highly alkaline environment. Extremophiles 4, 145-155.

Stanley, S. H., Prior, S. D., Leak, D. J. \& Dalton, H. (1983). Copper stress underlies the fundamental change in intracellular location of methane mono-oxygenase in methane-oxidizing organisms: studies in batch and continuous cultures. Biotechnol Lett 5, 487-492. 
Theisen, A. R. \& Murrell, J. C. (2005). Facultative methanotrophs revisited. J Bacteriol 187, 4303-4305.

Thompson, J. D., Gibson, T. J., Plewniak, F., Jeanmougin, F. \& Higgins, D. G. (1997). The CLUSTAL_X windows interface: flexible strategies for multiple sequence alignment aided by quality analysis tools. Nucleic Acids Res 25, 4876-4882.

Trotsenko, Y. A. \& Khmelenina, V. N. (2002). The biology and osmoadaptation of haloalkaliphilic methanotrophs. Microbiology (English translation of Mikrobiologiia) 71, 123-132.

Tsien, H. C. \& Hanson, R. S. (1992). Soluble methane monooxygenase component B gene probe for identification of methanotrophs that rapidly degrade trichloroethylene. Appl Environ Microbiol 58, 953-960.
Wartiainen, I., Grethe Hestnes, A., McDonald, I. R. \& Svenning, M. M. (2006). Methylocystis rosea sp. nov., a novel methanotrophic bacterium from Arctic wetland soil, Svalbard, Norway $\left(78^{\circ} \mathrm{N}\right)$. Int J Syst Evol Microbiol 56, 541-547.

Wayne, L. G., Brenner, D. J., Colwell, R. R., Grimont, P. A. D., Kandler, O., Krichevskey, M. I., Moore, L. H., Moore, W. E. C., Murray, R. G. E. \& other authors (1987). International Committee on Systematic Bacteriology. Report of the ad hoc committee on reconciliation of approaches to bacterial systematics. Int J Syst Bacteriol 37, 463-464.

Whittenbury, R., Phillips, K. C. \& Wilkinson, J. F. (1970). Enrichment, isolation, and some properties of methane-utilizing bacteria. J Gen Microbiol 61, 205-218. 